International Journal of Current Advanced Research

ISSN: O: 2319-6475, ISSN: P: 2319 - 6505, Impact Factor: SJIF: 5.995

Available Online at www.journalijcar.org

Volume 6; Issue 3; March 2017; Page No. 3072-3074

DOI: http://dx.doi.org/10.24327/ijcar.2017.3074.0184

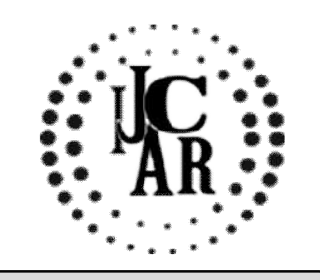

Research Article

\title{
EFFECT OF VARIOUS HERBAL TOOTHPASTES IN REDUCING THE STREPTOCOCCUS MUTANTS COUNT
}

\author{
Oviya.V.J and Geetha. R. V
}

Saveetha Dental College and Hospitals, Saveetha University, Chennai

\begin{tabular}{l}
\hline A R T I C L E I N F O \\
\hline Article History: \\
Received $11^{\text {th }}$ January, 2017 \\
Received in revised form $19^{\text {th }}$ February, 2017 \\
Accepted $22^{\text {nd }}$ March, 2017 \\
Published online $28^{\text {th }}$ April, 2017 \\
\end{tabular}

\section{Key words:}

Herbal, toothpaste, antibacterial, streptococcus mutans, dental caries, agar well diffusion

\begin{abstract}
A B S T R A C T
Aim \& Objective: To investigate the effect of various herbal toothpaste in reducing the count of streptococcus mutants.

Background: Streptococcus mutans is a facultatively anaerobic, gram-positive coccus commonly found in the human oral cavity and is a significant contributor to tooth decay. Early colonizers of the tooth surface are mainly Neisseria spp. and streptococci, including S. mutans. The growth and metabolism of these pioneer species changes local environmental conditions. Thereby enabling more fastidious organisms to further colonize after them, forming dental plaque. The combination of plaque and acid leads to dental decay. Practice of good oral hygiene including daily brushing, flossing and the use of appropriate mouthwash can significantly reduce the number of oral bacteria, including S. mutans and inhibit their proliferation. The objective of this study is to investigate the effect of various herbal toothpaste in reducing the count of streptococcus mutants by invitro method.
\end{abstract}

Materials and method: Five different commercially available herbal toothpastes were chosen as the samples. Culture was carried out using agar well diffusion method.Pure cultures of streptococcus mutants were obtained which was isolated using selective media Mutans - Sanguis agar.The zones of incubation were measured in mm diameter after the period of $24 \mathrm{hrs}$.

Result: Sample A with miswak extract has shown the highest zone of incubation measuring diameter of $39 \mathrm{~mm}$. Hence it is clear that, miswak extract in the toothpaste has a greater effect in reducing the mutants counts. It has the greater effect than the chlorexdine control.

Copyright $₫ 2017$ Oviya.V.J and Geetha. $\boldsymbol{R}$. V. This is an open access article distributed under the Creative Commons Attribution License, which permits unrestricted use, distribution, and reproduction in any medium, provided the original work is properly cited.

\section{INTRODUCTION}

Over 400 species of both aerobic and anaerobic bacteria colonise our oral cavity. Anaerobic bacteria outnumber their aerobic counterparts by a ratio of $10: 1$ to $100: 1$. These organisms inhabit the teeth, the gingival crevice, the mucous membranes, the dorsum of the tongue and saliva [1]. At birth the oral cavity is sterile but rapidly becomes colonized from the environment, particularly from the mother in the first feeding [2]. Dental caries is a disease, in which microbial fermentation of dietary carbohydrates forms lactic and other acids that leads to localized demineralization and destruction of the teeth. A cariogenic biofilm at a single tooth site may contain one-half-billion bacteria, of which species of mutansstreptococci are critical components. The characteristics contributing their cariogenicity are; ability to transport sugar, produces acid, tolerates acid's and produce

\section{*Corresponding author: Oviya.V.J}

Saveetha Dental College and Hospitals, Saveetha

University, Chennai extracellular and intracellular polysaccharides[3].Various measures proposed for the prevention of dental diseases include antibacterial measures, dietary measures, modification in plaque metabolism and increasing resistance to tooth attack[2]. Mechanical plaque control measures, such as toothbrushes, dental floss, toothpicks and interdental brushes used in conjunction with chemical plaque control aids, e.g. mouthrinses and medicated toothpastes are very popular in aiding oral hygiene [4]. But in most people, brushing alone is inadequate to remove the biofilm completely which may leads to the dental caries and periodontal diseases. Hence herbal toothpastes with antimicrobial activity can be used to maintain good oral hygiene. The main purpose of this study is to analyse the effects of various herbal toothpastes in reducing the streptococcus mutants count which colonise to form dental caries.

\section{MATERIALS AND METHODS}

Before starting this study, various brands of commercially available herbal toothpastes were obtained. Five toothpastes 
with different ingredients (Table.1) were chosen due to the constraints pertaining to available time and expenditure. Pure cultures of streptococcus mutants were obtained which was isolated using selective media Mutans - Sanguis agar [Hi media M977], and maintained in nutrient agar slope at $4^{\circ} \mathrm{C}$ in department of Microbiology, Saveetha Dental College.

Table 1 Various ingredients of each toothpastes

\begin{tabular}{cc}
\hline $\begin{array}{c}\text { Toothpaste } \\
\text { number }\end{array}$ & Ingredients \\
\hline 1 & $\begin{array}{c}\text { Calcium carbonate, Sorbitol, water, silica, sodium lauryl } \\
\text { sulfate, flavour, miswak extract, cellulose gum, carrageenan, } \\
\text { sodium silicate, sodium saccharin, formaldehyde } \\
\text { Maricha(Piper nigrum), pipali(Pipet longum), }\end{array}$ \\
& $\begin{array}{c}\text { Shunthi(Zingiber officinale), Tomar(Zanthoxylum armatum), } \\
\text { Lavanga(Syzygium aromaticum), Karpura(Cinnamomum } \\
\text { camphora), Pudina(Mentha species), gairic powder }\end{array}$ \\
Indian almond, common jujube, currant, Sarsaparilla, \\
Cinnamon, Sappan wood, Persian walnut, Rose apple, \\
Medlar, Barleria prinoitis, Prickly ash, Asian Holly Oak, \\
Bedda Nur, Bengal Madder, Bishop's Weed, Catechu, \\
Mayweed, Geranium, menthol, thymol, oils of clove, \\
eucalyptus, peppermint
\end{tabular}

Culture was carried out using agar well diffusion method. Broth culture of the bacterial culture of the bacterial strain was adjusted to $0.5 \mathrm{McFarland}$ turbidity standard. Lawn culture of the test organism was made on the Muller Hinton agar plates using sterile cotton swab and the plates were dried for 15 minutes. A sterile cotton swab was used to make wells measuring $6 \mathrm{~mm}$ diameter and samples were introduced directly on the wells. The zones of incubation were measured in $\mathrm{mm}$ diameter after the period of $24 \mathrm{hrs}$. The results were analysed and noted.

\section{RESULTS AND DISCUSSION}

Nowadays, most of the people use toothbrush and toothpastes for maintaining oral hygiene. So the mechanical and chemical form of oral hygiene aids help in preventing oral diseases like dental caries and periodontal diseases. Many of the toothpastes are well marketed with their highlighted benefits. Many of the products claims to have antimicrobial activity resulting in the dilemma of the consumers. Hence this research is carried out to evaluate the invitro antibacterial activity of commercially available herbal toothpastes.

The antibacterial activity of the toothpastes was screened by using modified well diffusion technique and the zone of inhibition was measured in $\mathrm{mm}$ diameter.The results were analysed and tabulated (Table.2 and Graph.1).

Table 2 Zone of inhibition formed by each toothpastes

\begin{tabular}{ccccccc}
\hline & S1 & S2 & S3 & S4 & S5 & $\begin{array}{c}\text { Chlorexdine } \\
\text { mouthwash }\end{array}$ \\
\hline $\begin{array}{c}\text { Zone of } \\
\text { inhibition(mm) }\end{array}$ & 39 & 22 & 19 & 22 & 19 & 27 \\
\hline
\end{tabular}

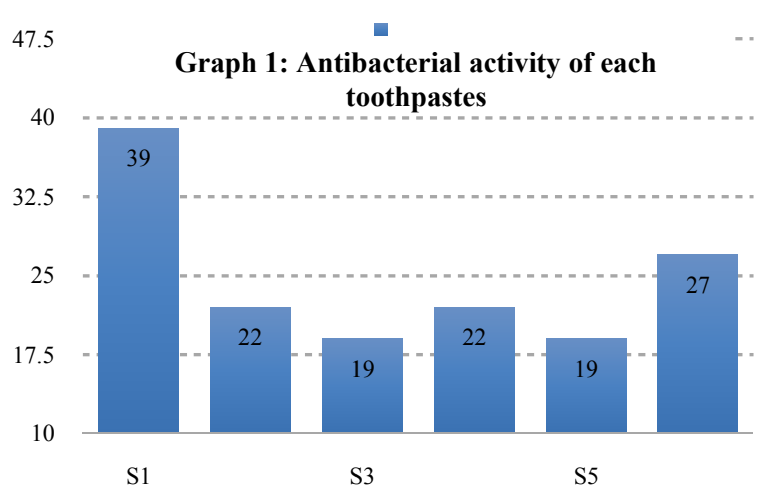

From the results, it is clear that the toothpaste with miswak content (toothpaste.1) shows the highest zone of inhibition measuring $39 \mathrm{~mm}$ diameter. It has the greater effect than the chlorexdine control which forms the zone of incubation of $27 \mathrm{~mm}$.
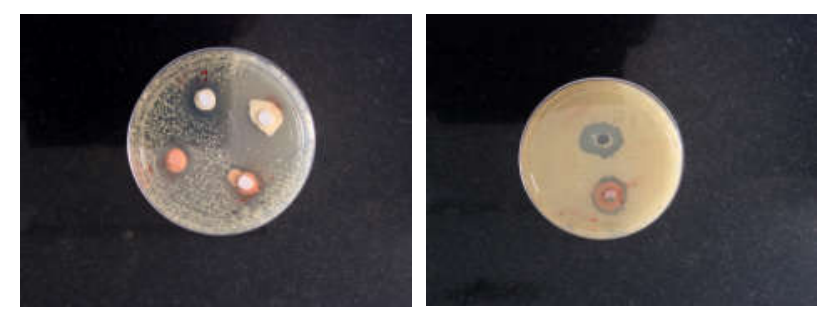

The least antibacterial activity was exhibited by the toothpaste. 3 and toothpaste.5. This may be due to the ingredients present which may have least antibacterial activity against streptococcus mutants.

\section{CONCLUSION}

From this study, it is clear that folk medicine is can be effective as the modern medicine against pathogens. The use of herbal medicine is both economic and safe alternative to treat diseases. Normal toothpaste contains chemicals like fluoride, saccharin etc., Excess use of these contents could damage the tooth surface and causes the teeth to become mottled. Since herbal toothpastes are devoid of these contents and effective in reducing mutants count, use of these should be encouraged.

\section{References}

1. Evaldson, G., A. Heimdahl, L. Kager and C. E. Nord. The normal human anaerobic microflora. Scand J. Infect. Dis. Suppl. 1982, 35: 9-15.

2. Amreenmunir, Javeria umar, A Hameed et.al. The Effect of commercially available local brand of toothpastes against oral bacteria. Pakistan Oral \& Dent. Jr. 25 (1) June 2005, 35-40.

3. Marsh, P. D. Role of the oral microflora in health. Microb. Ecol. Health Dis. 2000, 12: 130-137.

4. Maria Kurian, Geetha. R.V. Effect Of Herbal And Fluoride Toothpaste On Streptococcus Mutans - A Comparative Study. J. Pharm. Sci. \& Res. Vol. 7(10), 2015, 864-865

5. Geetha R.V, Anitha Roy. In Vitro Evaluation of Anti Bacterial Activity Three Herbal Extracts on Methicillin Resistant Staphylococcus aureus [MRSA]. J. Pharm. Sci. \& Res. Vol.5(10), 2013, 207 - 209 
6. Kallahalli Mruthyuenjaya Roopavathi et.al., Antimicrobial Efficacy of Commercially Available Toothpastes-An In vitro Study. Journal of Young Pharmacists Vol 7, Issue 3, Jul-Sep 2015.

7. Zainab Dakhil Degiam, Anin vitro antimicrobial activity of six commercial toothpastes, Thi-Qar Medical Journal (TQMJ): Vol(4) No(4):2010(127-133)

8. Ghapanchi J, Kamali F, Moattari A, Poorshahidi S, Shahin E, Rezazadeh F, Khorshidi H, Jamshidi S. In vitro comparison of cytotoxic and antibacterial e ects of 16 commercial toothpastes. J Int Oral Health 2015;7(3):39-43.
9. M.A. Fazeelath Banu, Geetha R.V.Evaluation of Antimicrobial Efficacy of Essential Oils on Streptococcus Mutans, Int. J. Pharm. Sci. Rev. Res., 33(1), July-August 2015; Article No. 23, Pages: 119-121.

10. Sweta and Geetha, Invitroantibacterial activity of clove and pepper on streptococcus mutans, Asian J Pharm Clin Res, Vol 8, Issue 5, 2015, 269-270.

11. S.Mounika et al p, Association of Streptococcus Mutants and Streptococcus Sanguis in Act of Dental Caries, J. Pharm. Sci. \& Res. Vol. 7(9), 2015, 764766.

12. Sriram. S et.al., Antibacterial evaluation of herbal extracts against Streptococcus mutans: An invitro study, Journl of chemical and pharmaceutical research, 2014, 6(1):678-680.

\section{How to cite this article:}

Oviya.V.J and Geetha. R. V (2017) ' Effect of Various Herbal Toothpastes In Reducing the Streptococcus Mutants Count', International Journal of Current Advanced Research, 06(04), pp. 3072-3074.

DOI: http://dx.doi.org/10.24327/ijcar.2017.3074.0184 